\title{
KALENDARZ WOJENNY POSPOLITEGO RUSZENIA W CZASACH WŁADYSŁAWA JAGIEŁŁY
}

\begin{abstract}
$\mathrm{S}$ zlacheckie pospolite ruszenie w czasach Władysława II Jagiełły było podstawową częścią armii Królestwa Polskiego. Nie dziwi zatem, że w przeszłości wielokrotnie przyciągało uwagę historyków. W pracach podejmowano przede wszystkim aspekty prawne służby wojskowej szlachty ${ }^{1}$. Z kolei udział rycerstwa w wojnach był ukazany zarówno w opracowaniach poświęconych poszczególnym konfliktom, jak i w przekrojowych pracach dotyczących wojskowości ${ }^{2}$. Celem tego artykułu jest zebranie informacji o udziale pospolitego ruszenia w wojnach i stworzenie swego rodzaju kalendarza militarnej aktywności rycerstwa w okresie rządów Władysława II. Zestawienie takie pozwoli przede wszystkim na ustalenie czasu spędzanego przez rycerstwo na wojnie oraz częstotliwość,
\end{abstract}

${ }^{1} \mathrm{Z}$ zakresu tej problematyki wymienić należy przede wszystkim opracowania: J. FrIEDBERG, Pospolite ruszenie $w$ Wielkopolsce $w$ drugiej połowie XV wieku, Lwów 1900; Materyały do dziejów pospolitego ruszenia z lat 1497 i 1509, zebrane $w$ części przez ś.p. A. Pawińskiego, red. S. KutrzebA, „Archiwum Komisji Historycznej” 1902, t. IX; S. Kutrzeba, Historja ustroju Polski w zarysie, t. I: Korona, Kraków 1931; Z. SPIERALsKi, Wymiar stużby w pospolitym ruszeniu, „Studia i Materiały do Historii Wojskowości” 1960, t. VI. Z nowszych opracowań wymienić należy pracę K. ŁoPATECKIEGO, Organizacja, prawo i dyscyplina w polskim i litewskim pospolitym ruszeniu (do połowy XVII wieku), Białystok 2013, a także K. GInTer, Udział szlachty polskiej w pospolitym ruszeniu w XIV i XV wieku. Aspekty prawne i stan faktyczny, Kraków 2008, tam też zebrana starsza literatura.

${ }^{2}$ Spośród licznych opracowań poświęconych poszczególnym wojnom w czasach Władysława Jagiełły należy wymienić: M. BIskuP, Wojny Polski z zakonem krzyżackim 1308-1521, Gdańsk 1993; A. LewICKI, Powstanie Świdrygiełty. Ustęp z dziejów unii Litwy z Koroną, Oświęcim 2015; J. Sperka, Wojny króla Władysława Jagiełty z księciem opolskim Władysławem (1391-1396), Wodzisław Śląski 2011; S. Jóźwiak, K. Kwiatkowski, A. Szweda, S. Szybkowski, Wojna Polski i Litwy z zakonem krzyżackim w latach 1409-1411, Malbork 2010; P. KARP, Polsko-husycka wyprawa zbrojna przeciw zakonowi krzyżackiemu w roku 1433, Zielona Góra 2017. 
z jaką powoływano rycerzy pod broń. Chcąc oszacować wysiłek szlachty związany ze służbą wojskową, należy też uwzględnić okres poświęcony na przygotowanie do wyprawy i dotarcie na miejsce koncentracji. Pozwoli to również określić, ile czasu potrzebowało pospolite ruszenie na osiągnięcie gotowości bojowej. Dzięki kalendarium wypraw możliwe będzie stwierdzenie, czy armia królewska była w stanie operować bez względu na porę roku, czy też ograniczała swą aktywność do miesięcy letnich. Ostatnim zagadnieniem poruszanym w artykule jest wpływ udziału rycerstwa w wyprawach na jego relacje z władcą. Dla przedstawienia tych zagadnień, prócz wymienionych już wydawnictw źródłowych i literatury, przydatne były przede wszystkim Roczniki Jana Długosza, materiały zawarte w Aktach grodzkich i ziemskich, a także opracowane przez Antoniego Gąsiorowskiego Itinerarium Władysława Jagiełły ${ }^{3}$.

$\mathrm{W}$ artykule niniejszym uwzględnione zostały wojny, w których brało udział rycerstwo zmobilizowane, czy to $\mathrm{w}$ ramach expeditio generalis, czy też expeditio particularis. Zwłaszcza ten pierwszy rodzaj mobilizacji praktykowano, planując wyprawę zaczepną ${ }^{4}$. Jednak i wyprawa częściowa była ogłaszana na potrzeby działań zaczepnych, o ile miały one charakter bardziej lokalny. Pominięte zostaną natomiast w tym opracowaniu działania wojenne, w których mieszkańcy Królestwa Polskiego wspierali armie innych państw jako ochotnicy. Ich uczestnictwo w takich wojnach, jeśli nawet odbywało się za przyzwoleniem króla, to było skutkiem własnej decyzji, a nie działaniem z polecenia monarchy. Pod względem chronologicznym opracowanie niniejsze obejmuje czasy od 1386 r., kiedy Władysław II po raz pierwszy powołał polskie rycerstwo pod broń, po schyłek roku 1433, gdy zmobilizował szlachtę po raz ostatni.

Jak wyżej wspomniano, Władysław II Jagiełło pierwszą mobilizację ogłosił już wiosną 1386 r. ${ }^{5}$ Jedną z najbardziej palących spraw, jaką wówczas musiał się zająć niedawno koronowany król, był trwający w Wielkopolsce od 1382 r. spór wokół sprawy następstwa tronu po zmarłym Ludwiku Węgierskim. Z jednej strony konfliktu stał ród Grzymalitów, będących zwolennikami Zygmunta Luksemburskiego, z drugiej natomiast przeciwni tej kandydaturze Nałęcze. Antagonizm przejawiał się nie tylko w politycznej debacie, ale dość szybko przerodził się w zbrojny konflikt, który skutkował zniszczeniem Wielkopolski. Choć koronacja

\footnotetext{
${ }^{3}$ J. DŁugosz, Roczniki czyli Kroniki stawnego Królestwa Polskiego, ks. 10-11, red. K. Pieradzka, Warszawa 1982 [dalej: DŁugosz], ks. 12 (1445-1461), red. J. Wyrozumski, Warszawa 2004; Akta grodzkie i ziemskie z czasów Rzeczypospolitej Polskiej z archiwum tak zwanego bernardyńskiego we Lwowie, [dalej: AGZ], t. III, Lwów 1872; A. GĄSIOROwsKI, Itinerarium Władysława Jagiełly 13861434, Warszawa 2015.

${ }^{4}$ K. Ginter, op. cit., s. 36.

${ }^{5}$ Itinerarium Władysława II potwierdza jego obecność w Krakowie do 26 III, następnie odnotowany został pobyt już w wielkopolskich Pyzdrach 18 IV. Biorąc pod uwagę dystans dzielący oba miasta (około $330 \mathrm{~km}$ ), wojsko wyruszyło najpewniej w drogę pod koniec marca, A. GĄsıorowski, op. cit., s. 36 .
} 
Jagiełły zamykała kwestię następstwa tronu, to król postanowił definitywnie wygasić wciąż tlący się spór między wielkopolskimi możnymi. W tym celu w kwietniu, wspólnie z Jadwigą, wyruszył do Gniezna i Poznania. Jako że nad Wartą wciąż utrzymywało się napięcie, Władysław powołał pod broń rycerstwo z ziemi krakowskiej i sandomierskiej. Jego asysta miała nie tylko zapewnić królewskiej parze bezpieczeństwo, ale też skłonić zwaśnione rody do uległości. Misja zakończyła się pomyślnie, konflikt udało się definitywnie zażegnać i nic nie wiadomo o tym, aby małopolskie rycerstwo musiało przy tym sięgać po broń6. Już 10 maja król przebywał w Radomiu, co pozwala sądzić, że małopolskie rycerstwo zostało odesłane do domów ${ }^{7}$. Cała wyprawa trwała więc około 6 tygodni.

W lutym 1387 r. Jadwiga Andegaweńska, wykorzystując fakt, iż sytuacja wewnętrzna na Węgrzech była daleka od stabilizacji, wyruszyła na Ruś, aby przyłączyć ją do Królestwa. Z 6 lutego pochodzi dokument Władysława Opolczyka, nawołujący mieszkańców Rusi do stawiania oporu królowej. Wynika z tego, że Andegawenka bądź przygotowywała się do drogi, bądź już w nią wyruszyła, skoro 18 lutego bawiła w Jarosławiu”. Jak pisze Długosz, wraz z „wojskiem złożonym z panów i rycerzy polskich udała się na Ruś" ${ }^{\prime 0}$. Z kolei 1 marca poświadczona jest obecność królowej w Gródku, $30 \mathrm{~km}$ na zachód od Lwowa ${ }^{11}$. Tydzień później Jadwiga gościła we Lwowie, gdzie wydała akt, którym potwierdziła stare i nadała nowe przywileje dla mieszczan ${ }^{12}$. Wszystkie miasta i zamki poddawały się królowej bez walki, a opuszczające je załogi węgierskie zbierały się w Haliczu. Tamtejszy wojewoda Benedykt nie oddał grodu, przy czym itinerarium Jadwigi wskazuje, że królowa, spodziewając się oporu, zaniechała dalszego marszu nie chcąc doprowadzać do otwartego konfliktu $\mathrm{z}$ Węgrami ${ }^{13}$. We Lwowie przebywała jeszcze 8 marca, a 19 tego miesiąca przebywała w Przemyślu ${ }^{14}$. Halicz dopiero

${ }^{6}$ J. Długosz argumentował, iż król zabrał wojsko: „By łatwiej móc zgnieść sprawców buntu”, DŁugosz, ks. 10 (1370-1405), s. 207; J. Krzyżaniakowa, J. Ochmański, Władysław II Jagiełło, Wrocław 1990, s. 154.

7 A. GąsIorowski, op. cit., s. 36.

8 AGZ, t. III, nr 39, s. 72-73.

${ }^{9}$ G. RutкowsкA, Itinerarium królowej Jadwigi 1384-1399, [w:] Dzieło Jadwigi i Jagiełty. W sześćsetlecie chrztu Litwy i jej związków z Polską, oprac. W. BıLIŃski, Warszawa 1989, s. 213.

10 Deugosz, ks. 10 (1370-1405), s. 237.

11 AGZ, t. III, nr 40, 41, s. 74-75.

12 AGZ, t. III, nr 42, s. 75-76.

13 J. Wyrozumski, Królowa Jadwiga. Między epoką piastowskq i jagiellońską, Kraków 2006, s. 107; J. Skrzy pek, Południowo-wschodnia polityka Polski od koronacji Jagiełly do śmierci Jadwigi i bitwy nad Worskla (1386-1399), Oświęcim 2015, s. 26-27; G. BŁAszczyк, Dzieje stosunków polsko-litewskich, t. II: od Krewa do Lublina, Poznań 2007, s. 113.

${ }_{14}$ Z Jarosławia do Lwowa przez Gródek jest około 120 km, natomiast ze Lwowa do Przemyśla blisko $100 \mathrm{~km}$. Przemarsz ze Lwowa pod Halicz i z powrotem oznaczał pokonanie dodatkowych 200 km, co nie daje pogodzić się z itinerarium królowej. Dziennik podróży królowej potwierdza zatem przypuszczenia J. Caro i J. Skrzypka, którzy słusznie domyślali się, że Jadwiga nie 
w początkach sierpnia opanował książę Witold, który przybył pod jego mury na czele oddziałów litewskich. Tym razem wojewoda Benedykt - nie mając widoków na odsiecz - skapitulował ${ }^{15}$. W walkach o Halicz polskie pospolite ruszenie nie brało już jednak udziału. Wyprawa Jadwigi na czele rycerstwa przebiegała w nietypowym dla działań wojennych terminie, bo pod koniec zimy. W jej trakcie nie doszło do walk, miała więc raczej charakter demonstracji siły i determinacji Andegawenki.

Znacznie większym wyzwaniem, tak dla Jagiełły, jak i jego wojska, był konflikt z Władysławem Opolczykiem. Ofensywę na ziemie pozostające pod panowaniem księcia poprzedził atak królewskich oddziałów na Kruszwicę i Raciążek. Pierwszy z celów należał do Wisława herbu Rogala, śląskiego rycerza pozostającego w służbie zakonu, który przejął ten gród jako zastaw od Siemowita IV. Z kolei zamek w Raciążku stanowił własność Henryka VIII, księcia legnicko-brzeskiego, a zarazem biskupa włocławskiego (od 1389). Opanowanie obu warowni położonych nad granicą z posiadłościami Opolczyka, miało ułatwić bezpośredni atak na ziemie księcia. Działania prowadzono niewątpliwie siłami lokalnego - kujawskiego rycerstwa, a niewykluczone, że także z udziałem rycerzy z Wielkopolski. Jak zakłada J. Sperka, oblężenie Kruszwicy rozpoczęto między 13 lipca a 15 sierpnia 1391 r., zakończyło się ono jednak niepowodzeniem. Pomyślny obrót przybrały natomiast sprawy pod Raciążkiem, który został opanowany, w czym pomógł starosta Piotr Lebel, wydając twierdzę Polakom ${ }^{16}$.

Tymczasem Jagiełło zbierał pospolite ruszenie z Małopolski w Krakowie, skąd wyruszył pod koniec sierpnia. Można założyć, że decyzję o tej wyprawie podjęto w pierwszej połowie lipca, skoro wtedy już prowadzono walki o Kruszwicę. Do Małopolan dołączyło wkrótce rycerstwo z Wielkopolski. Po opuszczeniu Łęczycy 2 września wojska królewskie uderzyły na ziemię gniewkowską, a 8 września przekroczyły Wisłę i dotarły do ziemi dobrzyńskiej, opanowując ją niemal w całości do 15 września. Nie zdołano zdobyć jedynie Bobrownik, obleganych od 10 września. Mimo to król zarządził odwrót, pozostawiając pod murami niezdobytego zamku Krystyna z Ostrowa z oddziałem, powierzając mu kontynuację oblężenia. Trwało ono aż do 21 listopada, kiedy wojska polskie odstąpiły po tym, jak pod Bobrownikami pojawiła się krzyżacka odsiecz ${ }^{17}$.

dotarła do miasta nad Dniestrem, G. Rut kowska, op. cit., s. 213; J. CARo, Geschschichte Polens, t. III: 1386-1430, Gotha 1869, s. 63; J. SKRZYPEK, op. cit., s. 28.

${ }^{15}$ Znany jest dokument datowany na 11 VIII 1397 r. zawierający warunki porozumienia książąt litewskich z wojewodą Benedyktem, Codex epistolaris Vitoldi Magni Ducis Lithuaniae 1376-1430, wyd. A. Prochaska, Cracoviae 1882, nr 35, s. 13; J. Nikodem, Witold, wielki książę litewski (1354 lub 1355 - 27 października 1430), Kraków 2013, s. 109-110; J. KRzYżaniakowa, J. Ochmański, op. cit., s. 159; O. HALECKI, Jadwiga Andegaweńska i kształtowanie się Europy Środkowowschodniej, Kraków 2000, s. 174-175.

${ }^{16}$ J. SPERKA, op. cit., s. 32-33.

17 J. Krzyżaniakowa, J. Ochmański, op. cit., s. 163; J. SPERKa, op. cit., s. 36-37. 
Król po opuszczeniu ziemi dobrzyńskiej na czele rycerstwa małopolskiego i łęczyckiego wkroczył do ziemi wieluńskiej, którą od 1370 r. z nadania Ludwika Węgierskiego władał Władysław Opolczyk. W chwili ataku książę ten znajdował się na Węgrzech, co z pewnością ułatwiło wojskom królewskim opanowanie Wielunia i okolic. Większość umocnionych punktów poddała się królowi bez walki. Do wyjątków należał zamek w Olsztynie k. Częstochowy, którego załoga broniła się przez trzy dni. Wojska królewskie napotkały też opór w Wieluniu. Wprawdzie mieszczanie - chcąc uniknąć strat - otworzyli przed Władysławem bramy, uznając tym samym jego prawa do panowania nad miastem, to załoga tutejszego zamku z burgrabią Stańczykiem z Rudy na czele, stawiła opór. Nie trwał on jednak długo, rycerze Jagiełły zdołali szybko zdobyć zamek, choć nie obeszło się przy tym bez strat. Długosz tak opisał tę kampanię: „w ciągu siedmiu dni wszystkie grody i miasto Wieluń $\mathrm{z}$ wyjątkiem jednego zamku Bolesławca przez poddanie się dostały się w ręce króla i jego wodzów"18.

Relacja kronikarza nie do końca jest precyzyjna. Jak wiadomo, prócz Wielunia wojska jagiellońskie musiały stoczyć walkę o Olsztyn, a wśród niezdobytych w 1391 r. zamków, oprócz wspomnianego Bolesławca, wymienić należy też Ostrzeszów. Te miejsca miały stać się celem ataku podczas kolejnej wojny z Opolczykiem. Co do czasu trwania kampanii, trudno stwierdzić, czy rację ma Długosz piszący o tym, że walki trwały tydzień. Itinerarium królewskie pozwala stwierdzić jedynie, że król opuścił ziemię wieluńską przed 18 października ${ }^{19}$. Tak czy inaczej, pierwsza wojna $\mathrm{z}$ księciem opolskim, a właściwie z broniącymi ziemi wieluńskiej książęcymi urzędnikami, trwała na pewno nie dłużej niż miesiąc. Zaś całość walk o opanowanie posiadłości Opolczyka rozciągnęła się na niespełna dwa miesiące.

Działania przeciwko księciu opolskiemu wznowiono w 1393 r., a celem ich było zdobycie Ostrzeszowa i Bolesławca. Tym razem Jagiełło nie wziął udziału w wyprawie, dowództwo powierzył Sędziwojowi z Szubina, staroście generalnemu Wielkopolski oraz Janowi Tęczyńskiemu, staroście sieradzkiemu, co oznacza, że armię miało tworzyć rycerstwo wielkopolskie (z sieradzkim). Król spotkał się $\mathrm{w}$ połowie stycznia $\mathrm{z}$ dowódcami, ustalając zapewne plan działań. Jeszcze

${ }^{18}$ Miasto Wieluń było otoczone murami, do których od wewnątrz przylegał zamek. Mimo że wchodził w obręb umocnień miejskich, stanowił warownię zdolną do samodzielnej obrony. Dowodzącego obroną Stańczyka, burgrabiego wieluńskiego zamku z nadania Władysława Opolczyka, Jagiełło skazał na śmierć, co może świadczyć, że pozostał on do końca wierny opolskiemu księciu, a wieluński zamek trzeba było zdobywać szturmem, a w jego trakcie na atakujących leciały kamienie, raniąc kilku, o czym wspomina J. Długosz. Gwoli ścisłości należy dodać, że egzekucji na Stańczyku nie wykonano, król wstrzymał ją w ostatniej chwili, a burgrabiemu nadał dobra na Rusi, doceniając w ten sposób jego waleczność, DŁugosz, ks. 10 (1370-1405), s. 281; T. Grabarczyк, T. NoWAK, Dzieje polityczne Wielunia (do 1580 roku), [w:] Wieluń. Dzieje miasta, t. I: do 1792 roku, red. A. Szymczakowa, Łódź-Wieluń 2011, s. 56-57; J. Sperka, op. cit., s. 41.

${ }^{19}$ Król 31 X był już we Lwowie, A. GĄsionowski, Itinerarium..., s. 42; J. SperkA, op. cit., s. 41. 
21 stycznia potwierdzona jest obecność Sędziwoja w Gnieźnie, co pozwala sądzić, że wyprawa wyruszyła nie prędzej niż na przełomie stycznia i lutego. O przebiegu kampanii wiadomo niewiele, pewne jest, że zdobyto Ostrzeszów, Bolesławiec natomiast zdołał się obronić i pozostał w ręku Władysława Opolczyka. Sądząc z tego, że Sędziwój 9 marca został wyznaczony do udziału w pertraktacjach z zakonem, które miały się odbyć 23 marca w Inowrocławiu, a starosta Jan w połowie marca był już w Tęczynie, można przypuszczać, że walki w ziemi wieluńskiej zakończyły się na przełomie lutego i marca. Kampania nie trwała zatem długo, poprzedzona zapewne jeszcze krótszymi przygotowaniami.

Zbrojne kroki przeciwko Opolczykowi wznowiono latem 1393 r., tym razem atakując wprost księstwo opolskie. Na czele wojsk stali Spytek z Melsztyna, wojewoda krakowski oraz znany już z poprzedniej kampanii Sędziwój z Szubina. Obecność tych właśnie dowódców może świadczyć, że w wyprawie uczestniczyło zarówno rycerstwo krakowskie, jak i kaliskie ${ }^{20}$. Najazd prócz Opolszczyzny dotknął ziemie znajdujące się pod panowaniem bratanków księcia opolskiego, którzy w konflikcie opowiedzieli się po jego stronie. Dwóch z nich: Bolesław IV i Jan Kropidło podpisało w początkach listopada rozejm, który obowiązywał do grudnia. Działania wojenne wznowili książęta śląscy w styczniu 1394 r. Tym razem walki koncentrowały się wokół fortalicium w Pławnowicach, które stanowiły najdalej wysunięty w stronę księstwa opolskiego umocniony punkt w rękach polskich. Obroną twierdzy dowodził Spytek z Melszytna, nic nie wskazuje, aby tym razem pod broń zwoływano rycerstwo. $\mathrm{Z}$ odsieczą oblężonej załodze nadeszła zapewne królewska chorągiew nadworna, co nastąpiło przed 22 lutego ${ }^{21}$.

Podczas drugiej wojny z Władysławem Opolczykiem chorągwie rycerskie pod broń powoływano dwukrotnie. Po raz pierwszy wzięły udział w wyprawie, która rozegrała się w lutym. Zimowa pora nie sprzyjała dłuższym działaniom i dlatego wojsko dosyć szybko wróciło do domów, poprzestając na zdobyciu Ostrzeszowa, rezygnując z walk o Bolesławiec. Działania wznowiono latem. Tym razem miały one zdecydowanie charakter ofensywny, najechano bowiem śląskie włości księcia Władysława i jego sojuszników. W obu przypadkach rycerstwo powołano pod broń $\mathrm{w}$ ramach expeditio particularis. W kampanii lutowej wzięły najpewniej udział chorągwie: sieradzka, kaliska a może też poznańska. Latem skorzystano z rycerzy ziemi krakowskiej, kaliskiej, ale nie wykluczone też, że ponownie z ziem: poznańskiej i sieradzkiej.

${ }^{20}$ Sędziwój z Szubina prócz tego, że był starostą generalnym piastował urząd wojewody kaliskiego, co może oznaczać, że z Wielkopolski w kampanii brało udział jedynie rycerstwo kaliskie, tak jak z Małopolski tylko rycerstwo ziemi krakowskiej.

${ }^{21}$ J. SPERKA, op. cit., s. 51-53. 
Przygotowania do trzeciej wojny $\mathrm{z}$ księciem opolskim rozpoczęto $\mathrm{w}$ początkach czerwca 1396 r. $^{22}$ Zebrane wojsko pod osobistym dowództwem króla wyruszyło po 14 lipca, kierując się przez ziemię wieluńską na Opole, którego bronili bratankowie Władysława Opolczyka. Po krótkim, ale intensywnym oblężeniu miasto skapitulowało i 6 sierpnia Jagiełło zawarł pokój z książętami. Zapewne spod Opola wojska udały się pod ostatni bastion księcia Władysława w ziemi wieluńskiej - Bolesławiec, który tym razem został zdobyty. Niestety, nie wiadomo, kiedy to nastąpiło. Pierwsza pewna informacja o tym, że zamek nad Prosną był w rękach polskich pochodzi dopiero z 18 stycznia 1397 r. Można jednak sądzić, że Bolesławiec opanowano jeszcze w sierpniu. Świadczy o tym fakt, że już w końcu tego miesiąca wznowiły swoją działalność sądy, np. w Łęczycy pierwsza sesja odbyła się już 29 sierpnia, a we wrześniu działały sądy w pozostałych ziemiach ${ }^{23}$. W tym przypadku preparacje do wyprawy trwały około 6 tygodni i chyba tyleż same działania zbrojne.

O ile w poprzednich dwóch wojnach z Opolczykiem, Jagiełło desygnował wojska złożone głównie z rycerstwa ziem sąsiadujących z książęcymi posiadłościami, o tyle na ostatnią kampanię ogłosił expeditio generalis i osobiście poprowadził je na Opole. Użyta w 1396 r. armia była więc z pewnością liczniejsza niż ta w poprzednich kampaniach. Mógł to być czynnik, który zadecydował o tak pomyślnym jej przebiegu. Podobnie jak wcześniejsze walki z Opolczykiem, zmagania trwały około miesiąca.

$\mathrm{Na}$ znacznie większą skalę prowadzone były działania przeciwko zakonowi krzyżackiemu. Początek tych zmagań przypadł na 16 sierpnia 1409 r., kiedy zakon zaatakował i zajął ziemię dobrzyńską. Wkrótce jego wojska wtargnęły do Krajny, w okolice Wałcza, a przede wszystkim na Kujawy, gdzie zajęły Bydgoszcz. Choć w Królestwie spodziewano się tego konfliktu, to mimo wszystko działania zbrojne podjęte przez zakon zaskoczyły stronę polską.

W odpowiedzi na krzyżacki atak król powołał szlachtę pod broń. Wielkopolanie - przynajmniej częściowo - zebrali się w ciągu 2 tygodni i na przełomie sierpnia i września dokonali nawet wypadu na Nową Marchię, doznając tam jednak porażki. Jako miejsce koncentracji dla rycerstwa z Małopolski wyznaczono Wolbórz. Stamtąd po 12 września z królem na czele wyruszyli do Łęczycy, gdzie dołączyły chorągwie wielkopolskie. W miesiąc po rozpoczęciu wojny przez zakon, armia Jagiełły była gotowa do walki. Dalej już wspólnie wojska królewskie udały się pod Bydgoszcz, gdzie od 28 września do 6 października prowadziły

${ }^{22} 2$ VI zawieszono roki ziemskie w Stopnicy (ziemia sandomierska), zaś 3 VI w Wiślicy, w Łęczycy ostatnie rozprawy odbyły się 20 VI, w Poznaniu - 3 VII, a w Pyzdrach - 13 VI, ibidem, s. 69-71.

${ }_{23}$ Codex diplomaticus Regni Poloniae et Magni Ducatus Lituaniae, t. I, cz. 1-2, wyd. M. Dogiel, Vilnae 1758, nr V, s. 539-540; A. GĄSIOROWski, op. cit., s. 48; J. SPERKA, op. cit., s. 76-82. 
oblężenie grodu, zakończone jego odzyskaniem. Tym razem Jagiełło powołał pod broń zarówno szlachtę wielkopolską, jak i małopolską, co świadczy o poważnym potraktowaniu zagrożenia.

Wkrótce po opanowaniu Bydgoszczy przez wojska Jagiełły zawarto rozejm, który obowiązywać miał do 24 czerwca $1410 \mathrm{r}$. Na mocy układu strony zatrzymywały zdobyte ziemie, a spór miał rozstrzygnąć Wacław IV. Od początku liczono się z wyrokiem niekorzystnym dla Polski, o czym świadczy fakt, iż nie czekając na werdykt, prowadzono przygotowania do kolejnej wojny. Jak się przyjmuje, generalna koncepcja planowanej kampanii opracowana została w już grudniu 1409 r. w Brześciu nad Bugiem, gdzie król spotkał się z Witoldem i arcybiskupem Mikołajem Trąbą ${ }^{24}$. Dzięki temu, w odróżnieniu od walk w 1409 r., kiedy to zakon był stroną atakującą, tym razem król mógł działania zaplanować starannie i samemu wybrać moment rozpoczęcia wojny.

Wydany w lutym 1410 r. przez Wacława wyrok, zgodnie z oczekiwaniami, okazał się niekorzystny dla Polski, co oznaczało, że po wygaśnięciu zawieszenia broni działania wojenne zostaną wznowione. Mając to na uwadze, już na przełomie kwietnia i maja Władysław II nakazał rycerstwu rozpoczęcie przygotowań wojennych, tak aby od razu po 24 czerwca móc uderzyć na państwo krzyżackie. Wiadomo, że Małopolanie, rycerstwo z Rusi Czerwonej, zaciężni zebrali się 24-25 czerwca w Wolborzu, podczas gdy Wielkopolanie ${ }^{25}$ dołączyli do króla z opóźnieniem, najpewniej dopiero 1 lipca, kiedy pozostała część armii była już nad Wisłą pod Czerwińskiem. Tam też stawiły się wojska litewskie i mazowieckie. Król był informowany o przebiegu koncentracji, zatem propozycja przedłużenia rozejmu o $10 \mathrm{dni}$, jaką przekazali mu posłowie Zygmunta Luksemburskiego w Wolborzu, była mu jak najbardziej na rękę. Zyskany dzięki temu czas pozwalał na dokończenie koncentracji wojsk. Zatem od momentu rozesłania wici do zebrania się całej armii upłynęło 8-9 tygodni.

Po przejściu na drugi brzeg Wisły (30 czerwca - 2 lipca) armia ruszyła ku granicy z państwem zakonnym, którą przekroczyła 9 lipca. Pospolite ruszenie, które wkroczyło wówczas na teren państwa zakonnego operowało w Prusach do 24 września. Wówczas Jagiełło odprowadza rycerstwo do ziemi dobrzyńskiej, gdzie „rozpuszcza swoje wojsko i odsyła każdego do jego ziemi” ${ }^{26}$. Powrót szlachty do domów nie oznaczał końca działań wojennych w Prusach. Wycofanie

${ }^{24}$ Elementem przygotowań do wojny była również misja Zawiszy Czarnego do Czech, który miał tam za zadanie znaleźć najemników gotowych wziąć udział w wojnie przeciwko zakonowi, T. Grabarczyк, Jazda zaciężna Królestwa Polskiego, Łódź 2015, s. 24-25.

${ }^{25}$ Chorągiew poznańska, a z nią zapewne i pozostałe oddziały wielkopolskie i kujawskie.

${ }^{26}$ Wojska przeszły do ziemi dobrzyńskiej, pokonując Drwęcę pod Golubiem, DŁugosz, ks. 10 i 11 (1406-1412), s. 172; A. Gąsiorowski, op. cit., s. 72; S. JóźwiAK, K. KWiAtKowsKi, A. SzwedA, S. SzYвкоWsкi, op. cit., s. 556. 
się głównych sił wykorzystały wojska krzyżackie, które przystąpiły do działań zaczepnych, odzyskując część utraconych wcześniej miast i zamków, a także podejmując wypady na pograniczne tereny Królestwa. Zaciężni i chorągiew nadworna, które to siły pozostawały cały czas do dyspozycji Władysława, nie wystarczały do skutecznego odparcia oddziałów zakonu. W związku z tym Jagiełło zmobilizował rycerstwo z kilku powiatów wielkopolskich, wspartych przez chorągwie własne Sędziwoja z Ostroroga i Dobrogosta Świdwy z Szamotuł. Oddziały te w pierwszych dniach października zaczęły nadciągać do Bydgoszczy i Nakła ${ }^{27}$. Kolejne 12 chorągwi przybyło do Bydgoszczy pod koniec października. Było to rycerstwo z ziemi wieluńskiej, poznańskiej, łęczyckiej, kujawskiej, sieradzkiej, dobrzyńskiej ${ }^{28}$.

Jak podaje Długosz, Władysław II, będąc 29 listopada w Inowrocławiu, „wzywa na nowo na wyprawę pruską Wielkopolskę i ziemię sieradzką, łęczycką, kujawską i dobrzyńską" ${ }^{29}$. Wojska te pod dowództwem Sędziwoja Ostroroga, wojewody poznańskiego dokonały wypadu na Pomorze Gdańskie, skąd po kilku dniach wróciły wioząc ze sobą bogate łupy ${ }^{30}$. Jeśli trzymać się relacji Długosza, w okresie od końca września do końca listopada król zwoływał pospolite ruszenie trzykrotnie, w odstępach miesięcznych. Wątpliwość budzą informacje o mobilizacjach w październiku i listopadzie. Kronikarz w obu przypadkach wymienia niemal te same ziemie (za drugim razem pomija wieluńską). Wydaje się, że nie było możliwe w tak krótkim czasie powoływanie tych samych chorągwi, zatem $\mathrm{w}$ tym przypadku Długosz najprawdopodobniej dwukrotnie wspomniał o tej samej mobilizacji.

Działania w Prusach wojska Jagiełły prowadziły do grudnia, kiedy w Nieszawie zawarto rozejm mający obowiązywać od 14 grudnia do 11 stycznia $1411 \mathrm{r}$. Król w tym czasie udał się do Małopolski, gdzie m.in. przygotowywał się do wznowienia działań. Nad granicę z zakonem, a konkretnie do Brześcia Kujawskiego powrócił 16 stycznia, prowadząc wojska „z ziem całego Królestwa Polskiego”31. Do armii królewskiej dołączył Witold na czele oddziałów litewskich. Wojska te przemieściły się jeszcze pod Raciążek, jednak poważniejszych działań nie podjęły. Ostatecznie, w związku z zawarciem 1 lutego pokoju w Toruniu, dzień później wojska zostały przez króla rozpuszczone ${ }^{32}$.

${ }^{27}$ DŁugosz, ks. 10 i 11 (1406-1412), s. 184; S. Jóźwiak, K. Kwiatkowski, A. Szweda, S. SzybKOWsKI, op. cit., s. 596-597.

${ }^{28}$ Wśród wojsk przybyłych do Bydgoszczy była piechota, S. Jóźwiak, K. KWIATKowsKi, A. SzWEDA, S. SzyBKowsKi, op. cit., s. 628.

29 DŁugosz, ks. 10 i 11 (1406-1412), s. 193.

${ }^{30}$ Ibidem; S. Jóźwiak, K. KwiatKowski, A. Szweda, S. SzybKowski, op. cit., s. 650.

${ }^{31}$ DŁugosz, ks. 10 i 11 (1406-1412), s. 200; Johann's von Posilge, officialis von Pomesanien, Chronik des Landes Preussen, Hrsg. E. Strehlke, [w:] Scriptores Rerum Prussicarum, t. III, Leipzig 1866, s. 324.

32 S. Jóźwiak, K. Kwiatkowski, A. Szweda, S. Szybkowski, op. cit., s. 711. 
W cieniu wojny toczącej się w Prusach rozgrywały się wydarzenia na południu Królestwa. Jagiełło, spodziewając się ataku ze strony Zygmunta Luksemburskiego, na wyprawę przeciwko zakonowi nie powołał rycerstwa z powiatów: sądeckiego, szczyrzyckiego i ziemi bieckiej ${ }^{33}$. To na nich spoczął obowiązek obrony Małopolski przed najazdem ze strony Węgier. Wojska te, zapewne od czerwca będąc pod bronią, czekały na atak. Jednak ostatecznie pod koniec października, uznając najpewniej, że nic się już nie wydarzy, zostały zdemobilizowane. Wówczas (prawdopodobnie po 24 października) nastąpił najazd wojewody siedmiogrodzkiego Ścibora ze Ściborzyc na ziemię sądecką, która pozostawała wówczas bez obrony. Atak ten spowodował ponowną mobilizację miejscowego rycerstwa, które wyruszyło w pościg za wycofującymi się wojskami węgierskimi. Po dotarciu pod Bardiów doszło do starcia, w którym zwycięstwo odniosły polskie chorągwie. Po złupieniu Górnych Węgier, Polacy powrócili do domów najpewniej w drugiej polowie listopada ${ }^{34}$.

Wojna z zakonem (1409-1411) stanowiła dla rycerstwa duże obciążenie, wielu rycerzy bowiem powoływanych było pod broń w jej trakcie kilkukrotnie. Warto zwrócić uwagę na ogłoszenie expeditio generalis w styczniu $1411 \mathrm{r}$. Kampania prowadzona zimą przez armię, powołaną z terenu całego Królestwa, należała do rzadkości. Inna sprawa, że nie trwała ona długo, a działań zbrojnych de facto wówczas nie podjęto.

Kolejna wojna z zakonem wybuchła w $1414 \mathrm{r}$. O rozesłaniu wici Władysław II zdecydował po konsultacjach $\mathrm{z}$ doradcami, jakie odbył podczas pobytu w Wielkopolsce, w drugiej połowie maja ${ }^{35}$. Małopolanie mieli się stawić 8 lipca do Wolborza, Wielkopolanie i Mazowszanie natomiast powinni dołączyć do nich w Zakroczymiu w połowie tego miesiąca. Tam też przybyły wojska litewskie. Zbieranie armii trwało więc około 8 tygodni. Wypowiedzenie wojny nastąpiło 18 lipca, po czym przekroczono Wisłę (24 lipca), a cztery dni później armia Jagiełły i Witolda dotarła do granicy z państwem krzyżackim. Następnego dnia rozpoczęto działania na jego terytorium, które objęły znaczne obszary. Wojnę, która do historii przeszła pod nazwą „głodowej”, zakończył rozejm zawarty 7 października w Brodnicy. Tego samego dnia wojska królewskie przeszły do ziemi dobrzyńskiej, gdzie zostały rozpuszczone do domów ${ }^{36}$.

Pospolite ruszenie na wyprawę do Prus powołano ponownie w 1419 r. Wici rozesłano wówczas na początku czerwca, zaraz po tym, jak wielki mistrz Michał

${ }^{33}$ Z.H. NowaK, Polityka pótnocna Zygmunta Luksemburskiego do roku 1411, Toruń 1964, s. 109.

${ }^{34}$ F. SiкоRA, Kilka uwag o konflikcie zbrojnym polsko-wegierskim w roku 1410, „Roczniki Naukowo-Dydaktyczne Akademii Pedagogicznej w Krakowie”, Prace Historyczne, t. XII, Kraków 1987, s. 105-117; S. Jóźwiak, K. Kwiatkowski, A. SzWedA, S. SzybKowski, op. cit., s. 656-700.

${ }_{35}$ M. BISKuP, op. cit., s. 101; A. GĄSIOROWSKI, op. cit., s. 81.

${ }^{36}$ M. Biskup, op. cit., s. 102-112. 
Küchmeister odrzucił propozycję rozstrzygnięcie sporu z Polską przez sąd polubowny ${ }^{37}$. Armia Jagiełły zebrała się w Czerwińsku przed 13 lipca. Tego dnia wygasał rozejm z zakonem, jednak za sprawą legatów papieskich, którzy przybyli do obozu wojsk Jagiełły, termin zakończenia zawieszenia broni dwukrotnie przedłużono o 8 dni. Po 22 lipca armia polsko-litewska wyruszyła z miejsca koncentracji w Czerwińsku na północ. Cały czas jednak trwały negocjacje, które 26 lipca zaowocowały porozumieniem i kolejnym przedłużeniem rozejmu. Wojsko będące wówczas już pod wsią Bądzyn, w ziemi zawkrzeńskiej, $10 \mathrm{~km}$ od granicy z państwem zakonnym zostało zawrócone i odesłane do domów ${ }^{38}$.

W 1422 r. doszło do wybuchu kolejnej wojny polsko-krzyżackiej. Wici rozesłano po naradzie w Inowrocławiu, która odbyła się 5 czerwca. Postanowiono na niej, że armia zbierze się 25 lipca w Czerwińsku. Rycerstwo miało więc ponad 7 tygodni na przyszykowanie się do wyprawy. O tym, że przygotowania ruszyły niezwłocznie świadczy raport krzyżackich wywiadowców, którzy już przed 17 czerwca donosili, że na Narwi i Wiśle Polacy budują mosty, które - jak nietrudno się domyślić - miały ułatwić przeprawę wojsku podczas wyprawy do Prus $^{39}$. Oficjalne wypowiedzenie zakonowi wojny przez Władysława II nastąpiło 15 lipca. Już dzień wcześniej rycerstwo małopolskie zebrało się w Wolborzu, po czym ruszyło do Czerwińska, gdzie 23 lipca dołączyło do Wielkopolan i Mazowszan. Zatem po 7 tygodniach od ogłoszenia wyprawy, wojska polskie były gotowe, by wyruszyć do Prus. Po przeprawieniu się przez Wisłę, wspólnie z wojskiem litewskim, ruskim i mołdawskim, armia rozpoczęła marsz ku granicy z zakonem, którą przekroczono najprawdopodobniej 29 lipca $^{40}$. Wojska Jagiełły operowały tym razem głównie w Pomezanii i ziemi chełmińskiej, niszcząc - zwłaszcza w obrębie tego drugiego terytorium - szereg miast i wsi. Pod koniec września królewska armia zatrzymała się nad rzeką Ossą, nieopodal jeziora Mełno. Tam właśnie rozpoczęto rozmowy pokojowe, które zakończono 27 września, podpisując pakt kończący wojnę $e^{41}$.

Wielki mistrz Paweł von Rusdorf wykorzystał fakt, iż rycerstwo z terenu całego Królestwa zostało wysłane pod Łuck i w końcu sierpnia 1431 r. wojska zakonne zaatakowały Kujawy, ziemię dobrzyńską i północno-zachodnią Wielkopolskę. Wyprawa przebiegła pomyślnie bowiem wojska krzyżackie nie napotykały na większy opór. Wiadomo, że na Kujawach chłopi sami próbowali organizować się w oddziały, aby odeprzeć najazd. Akcję tę zahamował jednak

\footnotetext{
37 A. GĄsiorowski, op. cit., s. 90.

38 M. Biskup, op. cit., s. 115-117.

39 S. JóźWIAK, Wywiad i kontrwywiad w państwie krzyżackim w Prusach, Malbork 2004, s. 107.

40 M. Biskup, op. cit., s. 125-127; A. GĄsiorowski, op. cit., s. 96.

${ }^{41}$ M. Biskup, op. cit., s. 132-139.
} 
starosta inowrocławski Mikołaj Tumigrała ${ }^{42}$. Natomiast w Wielkopolsce na wieść o przygotowaniach zakonu do ataku, już 12 sierpnia ogłoszono defensio terrae powołując pod broń wszystkich zdolnych do jej noszenia. Mobilizacja nie przybiegała jednak bezproblemowo, pora żniw sprawiała bowiem, że wojsko zbierało się z opóźnieniem. Pomimo to, zapewne właśnie sformowane wówczas oddziały, w większości złożone z chłopów, 3 września pokonały wojska inflanckiej gałęzi zakonu w starciu pod Dąbkami na zachód od Nakła nad Noteciąa ${ }^{43}$. Od ogłoszenia mobilizacji do zwycięskiej bitwy upłynęły zaledwie 3 tygodnie.

Konsekwencją układu, jaki Jagiełło zawarł z husytami w Pabianicach w lipcu 1432 r., była wspólna czesko-polska wyprawa przeciwko zakonowi przeprowadzona rok później. Oddziały „sierotek”, dowodzonych przez Jana Czapka z Sanu, przekroczyły Odrę pod Głogowem 18-19 maja 1433 r. Przeprawę zabezpieczał książę głogowski Henryk oraz obecny tam z ramienia króla Piotr Szafraniec z 200-konnym oddziałem. Szczegóły dotyczące dalszych poczynań zapadły zapewne podczas narady Jagiełły z Janem Czapkiem 25 maja w Poznaniu. Granicę z państwem zakonnym połączone wojska czesko-polskie przekroczyły 7 czerwca 1433 r., po czym skierowały się pod Dobiegniew i Strzelce Krajeńskie i zajęły oba miasta $^{44}$. Niedługo potem, bo 24 czerwca zebrało się w Kole pospolite ruszenie z ziem: krakowskiej, sandomierskiej, sieradzkiej, lubelskiej i wieluńskiej, w liczbie nieprzekraczającej 3000 ludzi. Dowodzone przez Sędziwoja z Ostroroga, przemieściło się do Międzyrzecza, gdzie dołączyły do nich oddziały Czapka ${ }^{45}$. Postanowiono, że w związku ze słabą już kondycją fizyczną Władysława Jagiełły, dowództwo nad całością sił miał objąć Mikołaj z Michałowa, kasztelan i starota krakowski $^{46}$. On to właśnie 15 lipca przyprowadził Małopolan pod Chojnice, oblegane już przez Czechów i Wielkopolan ${ }^{47}$. Miasta jednak nie udało się zdobyć, w związku z czym 15 sierpnia zakończono oblężenie i wyprawa ruszyła na północ, by na początku września dotrzeć pod Gdańsk. Pochód zatrzymał się nad Zatoką Gdańską, czyli „na kraju świata” - jak stwierdził w przemowie do swych żołnierzy Jan Czapek. Następnie wojska skierowały się na południe. Działania zakończył rozejm zawarty 13 września w krzyżackim Jasieńcu. Pospolite ruszenie zostało zapewne niedługo potem rozpuszczone, skoro dowodzący nim Mikołaj z Michałowa był 20 września u boku króla w Pyzdrach; tam też dotarli Czesi, by odebrać

42 Ibidem, s. 149.

43 P. KARP, Polsko-husycka wyprawa zbrojna przeciw zakonowi krzyżackiemu w roku 1433, Zielona Góra 2017, s. 48; M. BiskUP, op. cit., s. 147, 151-152.

44 P. KARP, op. cit., s. 169-173; T. GrabARCZYK, op. cit., s. 149-150.

45 A. Gąsionowski, Pobór do pospolitego ruszenia 1433 roku w Wielkopolsce, „Kwartalnik Historyczny” 1969, R. CXXVI, z. 1, s. 132.

46 DŁugosz, ks. 11 i 12 (1431-1444), s. 101.

47 M. Biskup, op. cit., s. 174. 
należne im wynagrodzenie. W ten sposób ostatnia kampania Władysława Jagiełły przeciwko zakonowi krzyżackiemu dobiegła końca. Formalne zakończenie wojny nastąpiło 31 grudnia 1435 r., czego już jednak Władysław II Jagiełło nie dożył ${ }^{48}$.

Po serii wypraw pospolitego ruszenia do Prus, w 1431 r. rycerstwo wzięło udział w wojnie, która była konsekwencją konfliktu ze Świdrygiełłą, zwolennikiem uniezależnienia się Litwy od Polski ${ }^{49}$. Poczynania litewskiego księcia zmusiły Jagiełłę do podjęcia stosownych kroków. Podczas pobytu w Sandomierzu, w drugiej połowie lutego, król podjął decyzję o zbrojnej wyprawie na Litwę ${ }^{50}$. Z kolei będąc na przełomie marca i kwietnia w Krakowie, polecil, aby we wszystkich ziemiach Królestwa rozpocząć przygotowania do wyprawy na Luck $^{51}$. Rycerstwo miało więc na preparacje co najmniej 10 tygodni. Jagiełło dał więc tym razem swemu wojsku więcej czasu na przygotowania, niż było to w przypadku wypraw do Prus.

Sytuacja uległa dalszemu zaostrzeniu w związku z przymierzem, jakie Świdrygiełło zawarł z zakonem, o czym 20 czerwca poinformował Władysława. Będący w Przemyślu król zareagował, nakazując 24 czerwca, aby w Krakowie szykowali działa (bombardas), strzały/pociski oraz inny sprzęt wojenny (res bellicas) i wszystko to słali pod Łuck $^{52}$. Zebrane już wojska małopolskie i ruskie Jagiełło podzielił na trzy kolumny. Dwie wysłał przodem, jedną na Zbaraż, drugą na Horodło. Sam natomiast, w asyście pozostałego wojska, podążał za tą ostatnią. Idące przodem oddziały wkrótce zajęły oba wspomniane grody oraz Włodzimierz,

48 Ibidem, s. 179-185, 196.

49 Wojska Świdrygiełły zajęły m.in. Horodło, Włodzimierz i Zbaraż, a na początku 1431 r. próbowały także zdobyć Smotrycz. Oblężenie zakończyło się po ośmiu dniach, gdy nadciągnęło polskie rycerstwo i rozbiło Litwinów. Nie jest jasne, jakie oddziały polskie przybyły na odsiecz Smotryczowi. DŁugosz (Annales seu cronicae incliti Regni Poloniae, lib. 11 et 12, Varsaviae 2001, s. 14) wspomina ogólnie, iż byli to „gentibus regiis”. Z kolei Jagiełło w liście z 14 VII 1431 r. pisał do wielkiego mistrza Pawła Russdorffa, że odsiecz Smotrycza przeprowadzili „fideles nostri ac huiusmodi violencias suffere non volentes, absque sciencia nostra direxerunt acies suas ad restringendum et repellendum eosdem ab obsidione castro predicti”, Codex epistolaris saeculi decimi quinti, oprac. A. LEWICKI, t. II: 1382-1445, Kraków 1891, nr 191, s. 259. A. LewiCKi (op. cit., s. 106) stwierdza, że była to „zebrana bez wiedzy królewskiej, odsiecz polska”. Pozostaje się zgodzić z tym badaczem, doprecyzowując jedynie, że z odsieczą nie nadeszły chorągwie pospolitego ruszenia. Biorąc pod uwagę, że oblężenie trwało tylko 8 dni, pod Smotrycz mogło dotrzeć jedynie rycerstwo ziem ruskich.

${ }^{50}$ DŁugosz, ks. 11 i 12 (1431-1444), s. 17; Obecność króla w Sandomierzu potwierdzona w dniach 14-23 II, A. Gąsiorowski, Itinerarium..., s. 117.

51 Według Długosza Jagiełło „transmisso in omnes terras regni sui ex Cracovia mandato, ut contra Luczskam in bellum procederent”, co A. Lewicki wprost określił jako rozesłanie wici, DŁUGosz, Annales..., lib. 11 et 12, s. 22; A. Lewicki, op. cit., s. 119. Jak wynika z itinerarium, król przebywał w Krakowie od 11 do 16 III, A. GĄsionowski, op. cit., s. 117-118; A. Lewicki, op. cit., s. 119; M. Plewczyński, Wojny Jagiellonów z wschodnimi i południowymi sąsiadami Królestwa Polskiego w XV wieku, Siedlce 2005, s. 23.

52 DŁugosz, Annales..., lib. 11 et 12, s. 24; A. GĄsiorowski, op. cit., s. 118. 
wszystkie jednak zostały wcześniej opuszczone i spalone. Warto odnotować, że 4 lipca 42 panów polskich wypowiedziało Świdrygielle wojnę. Król pod Horodło przybył prawdopodobnie 9 lipca i pozostał tam przez $12 \mathrm{dni}^{53}$. W tym czasie powiadomił europejskie dwory o wszczęciu wojny ze Świdrygiełłą, co należy uznać za formalne wypowiedzenie wojny. Dokonał także przeglądu swych wojsk, które składało się z rycerstwa z ziem: krakowskiej, sandomierskiej, lubelskiej oraz z Rusi. Jak łatwo zauważyć, u boku Władysława wciąż nie było chorągwi wielkopolskich. W dalszą drogę król na czele Małopolan wyruszył 21 lipca i po przekroczeniu Bugu kierował się na Łuck. Wielkopolanie dołączyli dopiero 28 lipca, gdy oddziały małopolskie zatrzymały się na postój koło wsi: Skurcze i Biskupice. Jak informuje Długosz, dowódcy wielkopolscy zostali przez króla zrugani zarówno za spóźnienie, jak i rozboje, które ich wojska czyniły po drodze. Bez względu na to, od tego momentu armia już w całości zmierzała w stronę Łucka, pod który dotarła w końcu lipca. Po zwycięskim starciu z wojskami Świdrygiełły nad Styrem Polacy przekroczyli rzekę, po czym przystąpili do oblężenia zamku. Trwało ono do 26 sierpnia, kiedy zawarty został rozejm kończący ostatecznie walki o Łuck. W związku z zaprzestaniem działań, Jagiełło 4 września zarządził odwrót. Dzień później podzielił swe wojsko na części, aby różnymi drogami wracało do domów.

Wojna łucka rozpoczęła się praktycznie w końcu czerwca 1431 r., choć formalne wypowiedzenie wojny nastąpiło później. Małopolanie uczestniczyli w działaniach zbrojnych przez dwa miesiące, natomiast Wielkopolanie, którzy dotarli na Ruś później, w wojnie brali udział jedynie przez miesiąc.

We wrześniu 1432 r. Władysław wysłał swych dworzan na Wołyń w celu odbicia zamku w Olesku, zajętego przez ludzi Świdrygiełły. Misja zakończyła się powodzeniem, co pozwoliło powierzyć chorągwi nadwornej kolejne zadanie. Tym razem oddział wysłano przeciwko Fedkowi z Ostroroga, który ze swym wojskiem operował na Podolu. Do dworzan dołączyli wówczas - jak dość enigmatycznie informuje Długosz - novarum gencium. Chodzi tu najpewniej o rycerstwo z województwa ruskiego, na co wskazuje obecność wśród dowódców tej wyprawy starosty ruskiego Wincentego z Szamotuł oraz wojewody ruskiego Jana Mężyka z Dąbrowy. Niewykluczony jest też udział ochotników z innych ziem Królestwa i Mazowsza ${ }^{54}$. Wojsko ruszyło na wschód w drugiej połowie października. Do starcia z oddziałami Fedka doszło 30 listopada pod Kopystrzyniem nad Marchawą.

53 Taką datę podaje Długosz, natomiast dokumenty poświadczają obecność króla pod Horodłem dopiero w dniach 14-21 VII, DŁugosz, Annales..., lib. 11 et 12, s. 24; A. LewiCKi, op. cit., s. 126-127; A. GĄsiorowski, op. cit., s. 118.

${ }_{54} \mathrm{~W}$ ustaleniu chronologii tych walk pomocna jest informacja o tym, że 15 października Władysław II Jagiełło nadał przywilej dla rycerstwa oleskiego, rozciągający prawo polskie na ten obszar. Oznacza to, że terytorium to musiało być już wówczas w polskich rękach, G. BŁAszczyк, Dzieje..., s. 678; M. PleWCZYŃski, op. cit., s. 34-35. 
Wojska królewskie odniosły tam zwycięstwo, mimo to nie zdołano odzyskać pełnej kontroli nad Podolem, a jedynie nad jego wschodnią częścią. O sukcesie powiadomił króla posłaniec wysłany przez zwycięskich dowódców. Jagiełło, ucieszony dobrymi wieściami, posłał wojsku dary w postaci szat i pieniędzy, co oznacza, że oddziały biorące udział w bitwie jeszcze nie powróciły. Król opuścił Lwów po 8 grudnia, a 14. tego miesiąca był już w Jarosławiu. Nic nie wiadomo, aby witał zwycięskie wojska, zatem w tym czasie musiały one być jeszcze w drodze. Do Lwowa musiały dotrzeć niedługo po wyjeździe Władysława, bowiem przekazano mu chorągwie zdobyte pod Kopystrzyniem. Król zaprezentował je pod koniec grudnia, podczas uroczystego wjazdu króla do Krakowa ${ }^{55}$. Biorąc pod uwagę kalendarium, można szacować czas wyprawy rycerstwa ruskiego i dworzan na Podole na około 2 miesiące.

W 1433 r. król zmuszony był raz jeszcze powołać rycerstwo pod broń. Wiązało się to z działaniami wojsk kniaziów: Fedki Nieświckiego i Aleksandra Nosa - dowódców Świdrygieły, którzy wiosną zaatakowali Brześć nad Bugiem. Chcąc ich odeprzeć, Jagiełło zwołał rycerstwo ziem ruskich, wsparte oddziałami mazowieckimi i wysłał je z odsieczą dla obleganego Brześcia. Zmusiło to Litwinów do odstąpienia spod zamku. Ponowna konfrontacja rycerstwa ziemi ruskiej z wojskiem Świdrygiełły nastąpiła pod Hrubieszowem, gdzie Hryćko Kierdejowicz rozbił oddziały księcia pińskiego Aleksandra Nosa. Trudności nastręcza precyzyjne ustalenie chronologii tych zdarzeń. Biorąc pod uwagę sytuację na Litwie, można omawiane wydarzenia umieścić niezbyt precyzyjnie na wiosnę $1433 \mathrm{r}^{56}$

O polskich oddziałach na Litwie słychać jeszcze przy okazji walk toczonych od schyłku września przez wielkiego księcia Zygmunta. W kolejnych tygodniach zajął on szereg grodów w południowo-wschodniej Litwie, a począwszy od 24 października przez trzy tygodnie - bez powodzenia - oblegał Mścisław ${ }^{57}$. Był to ostatni epizod zmagań ze Świdrygiełłą w 1433 r. Źródła wspominające o uczestniczących w nich Polakach nie precyzują, z jakim rodzajem wojska mamy do czynienia - czy działającym z królewskiego polecenia pospolitym ruszeniem z Rusi, czy może tylko ochotnikami. Brak także informacji, do kiedy pozostawali na służbie.

W okresie od 1386 r., kiedy Jagiełło po raz pierwszy wyruszył na czele małopolskiego rycerstwa do Wielkopolski, po 1433 r., gdy szlachta wspólnie z „sierotkami”

${ }^{55}$ DŁugosz, Annales..., lib. 11 et 12, s. 66, 73-77; A. GĄsıorowski, op. cit., s. 121-122; J. KrzYŻANIAKOWA, J. OCHMAŃSKi, op. cit., s. 300.

${ }^{56}$ DŁugosz, Annales..., lib. 11 et 12, s. 85; G. B£Aszczyк, op. cit., s. 680-681; L. Kolankowski, Dzieje Wielkiego Księstwa Litewskiego za Jagiellonów, t. I: 1377-1499, Oświęcim 2014, s. 194-195; M. PlewCzyński (op. cit., s. 38) stwierdza, że do najazdu na ziemię bełską i starcia pod Hrubieszowem doszło w połowie czerwca. Natomiast A. Lewicki (op. cit., s. 248, przyp. 21) przypuszcza, że rozegrały się one we wrześniu.

${ }^{57}$ A. LEWICKI, op. cit., s. 250. 
najechała państwo krzyżackie, rycerstwo powoływano pod broń co najmniej 22 razy, z czego siedmiokrotnie było to expeditio generalis ${ }^{5}$. W pozostałych wyprawach uczestniczyły chorągwie jedynie z wybranych ziem. Niekiedy brak informacji co do sposobu mobilizacji. Przykładem może być wojna Jagiełły z Witoldem w 1390 r. Wiadomo, że król zabrał ze sobą grupę rycerstwa polskiego, lecz źródła nie mówią nic o tym, kim oni byli. Wskazówką pewną może być chronologia wydarzeń. Konflikt wybuchł po 19 I, a Władysław, który był wówczas w Lublinie zdołał zebrać wojsko polskie i litewskie, na czele którego odbił najpierw Brześć, a następnie Kamieniec Litewski (12 II). Król miał więc niespełna 2 tygodnie na zebranie wojska. Tak błyskawiczna reakcja pozwala założyć, że zabrał ze sobą tylko chorągiew nadworną i ochotników ze wschodniej Małopolski. Na większą mobilizację nie było bowiem czasu $^{59}$. W przypadku mobilizacji obejmujących część ziem Królestwa występuje niekiedy problem z jednoznacznym określeniem, $\mathrm{z}$ jakich województw powołano pod broń rycerstwo ${ }^{60}$. Po zsumowaniu samych wzmianek o udziale rycerstwa poszczególnych prowincji (expeditio particularis) okazuje się, że Wielkopolanie stawali pod bronią czterokrotnie (1391, 1393, X 1410, 1433), do tego należy doliczyć mobilizację Łęczycan w 1391 r. i rycerstwa z powiatów przy granicy z państwem zakonnym we wrześniu $1410 \mathrm{r}$. Małopolanie byli mobilizowani częściej $(1386,1387,1391,1433)$, do tego dochodzi służba rycerstwa krakowskiego w 1393 r. Odrębną mobilizację szlachty kujawskiej odnotowano dwukrotnie (1391, X 1410). O rycerzach dobrzyńskich mówi się przy okazji koncentracji wojsk w październiku 1410 r. w Bydgoszczy. Rycerstwo ziem ruskich zmobilizowano w 1426 r., z myślą o wsparciu Zygmunta Luksemburskiego w walce z Turkami, ostatecznie jednak do wojny wówczas nie doszło ${ }^{61}$. Aktywnie uczestniczyło natomiast w wojnach ze Świdrygiełłą w latach 1432-1433. Sumując więc służbę rycerzy w expeditio generalis oraz expeditio praticularius, okaże się, że mieszkańców dwóch największych prowincji Władysław II powoływał pod broń 12 razy. Nie będzie zatem dalekie od prawdy stwierdzenie, że w czasach króla Jagiełły, przeciętny, nieuchylający się od służby rycerz, wyruszał na wojnę mniej więcej co 4 lata.

${ }^{58}$ Pospolite ruszenie planowano zwołać również w styczniu 1434 r., lecz ostatecznie do tego nie doszło.

59 J. Nikodem, op. cit., s. 132-134; A. Gąsiorowski, Itinerarium ..., s. 40.

${ }^{60}$ Przykładem może być mobilizacja ogłoszona w październiku 1410 r. Do Bydgoszczy stawiło się wówczas rycerstwo z powiatów leżących nad granicą z państwem krzyżackim, ale nie jest jasne, z których dokładnie. Jeśli wierzyć Długoszowi, niedługo potem powołano pod broń rycerstwo z województw: poznańskiego, łęczyckiego, sieradzkiego, a także z Kujaw i ziemi dobrzyńskiej. Zwraca uwagę brak na tej liście województwa kaliskiego, nie wiadomo, czy oznacza to, że rycerzy znad Prosny nie objęła wówczas mobilizacja, czy może jednak brak wzmianki o nich to tylko przeoczenie kronikarza.

${ }^{61}$ Jak czytamy w Rocznikach, pod bronią stanęło wówczas 5000 zbrojnych, DŁUGosz, ks. 11 (1413-1430), s. 233. 
Należy jednak zauważyć, że powyższe zestawienie nie wyczerpuje listy konfliktów, w których uczestniczyło polskie rycerstwo w okresie panowania Władysława II. Na terenach nadgranicznych dochodziło bowiem do starć na mniejszą skalę. O ich przebiegu i uczestnikach źródła z reguły wzmiankują zazwyczaj bardzo lakonicznie. Wiadomo, że niespokojnie było na ziemiach sąsiadujących z państwem krzyżackim ${ }^{62}$. Z kolei u schyłku panowania Jagiełły dochodziło do zbrojnych utarczek na obszarach sąsiadujących ze Śląskiem ${ }^{63}$. Wobec takich niespodziewanych ataków o lokalnym zasięgu odpór najeźdźcom stawić mogło jedynie rycerstwo zamieszkujące najbliżej ziem dotkniętych agresją. Tego rodzaju mniejsze starcia stanowiły kolejną okazję do sięgnięcia po broń. Pamiętać też należy, że mieszkańcy Królestwa Polskiego - czy to jako ochotnicy, czy zaciężni - służyli zbrojnie także na Litwie, Węgrzech, Śląsku, w Czechach, a zapewne także w innych krajach. Tak więc poddani Władysława Jagiełły, którzy z różnych powodów chcieli brać udział w wojnach, mieli do tego wiele okazji.

Częstotliwość wojen to tylko jeden $\mathrm{z}$ aspektów wojennego wysiłku rycerstwa. Kolejnym jest długotrwałość konfliktów, w których ono uczestniczyło. Warto zauważyć, że wyprawa wojenna absorbowała rycerza na długo przed przystąpieniem do walki. Pierwszym znakiem, że należy rozpocząć przygotowania były wici, które rozsyłano po tym jak zapadła polityczna decyzja wszczęcia wojny ${ }^{64}$. Wezwanie na wojnę musiało być rozesłane $\mathrm{z}$ odpowiednim wyprzedzeniem, tak aby zarówno każdy rycerz z osobna, jak i całe chorągwie osiągnęły gotowość bojową w odpowiednim terminie ${ }^{65}$.

${ }^{62}$ Np. przytoczony wyżej najazd krzyżacki w 1431 r., podczas którego doszło do bitwy pod Dąbkami.

${ }^{63}$ Przykładem może być atak Bolesława V, księcia opolskiego wraz z Dobiesławem Puchałą na Częstochowę wiosną 1430 r., lub rok później przemarsz oddziału husyckiego, wracającego na Śląsk po zrabowaniu Czerwonego Klasztoru. W tym ostatnim przypadku Czechom pod Lipowcem próbował zastąpić drogę oddział zorganizowany przez biskupa Zbigniewa Oleśnickiego, w którym znaleźli się m.in. „znakomici panowie i rycerze polscy”. Nie zdołali oni jednak stoczyć bitwy z szybko przemieszczającymi się husytami, DŁugosz, ks. 11-12 (1431-1444), s. 21-23; J. Rajman, Pogranicze śląsko-małopolskie w średniowieczu, Kraków 1998, s. 201; A. ProchasкA, Napad husytów na Częstochowę w 1430 r., „Kwartalnik Historyczny” 1907, R. XXI, s. 309-320.

${ }^{64}$ Najstarsza wzmianka, w której występuje termin „wici” pochodzi z 1325 r.: „Dummodo sit publicum edictum Regis per preconem, per ferale, wulgaliter dictum vicy", Kodeks dyplomatyczny katedry krakowskiej ś. Wacława, cz. 1: obejmująca rzeczy od roku 1166 do roku 1366, wyd. F. РієкоsiŃski, t. I, Kraków 1874, nr 134, s. 171.

${ }^{65}$ Nie wiadomo, czy w czasach Jagieły wysyłano już tzw. potrójne wici, bowiem informacja o nich pochodzi dopiero z $1490 \mathrm{r}$. W przypadku potrójnych wici - tercierestis, pierwsze dwa komunikaty nakazywały gotowość wojenną, trzeci był poleceniem natychmiastowego wymarszu, Codex epistolaris saeculi decimi quinti, oprac. A. Lewicki, t. III: 1392-1501, Kraków 1891-1894, nr 362; Materyały do dziejów pospolitego ruszenia..., s. 250; Z. GLOGER, Encyklopedia staropolska, Warszawa 1903, s. 426. 
O przygotowaniach do wojny i niezbędnym do tego czasie ciekawe informacje podaje Długosz w odniesieniu do przełomu lat 1433 i 1434. Fiasko rozmów pokojowych prowadzonych w Brześciu Kujawskim przez przedstawicieli Polski i zakonu spowodowało, że pojawiła się groźba wybuchu kolejnej wojny. Po przerwaniu rokowań w dniu 6 grudnia poselstwo polskie udało się do Łęczycy na spotkanie z Władysławem II. W wyniku wspólnej narady - mając na uwadze, że zawieszenie broni wygasa 25 grudnia - podjęto decyzję o rozpoczęciu przygotowań do wyprawy. Król polecił rozesłać wici, zalecając, aby pospolite ruszenie zebrało się 6 stycznia 1434 r. w Duninowie na pograniczu kujawsko-mazowieckim. Spotkanie, podczas którego zapadła decyzja o mobilizacji, odbyło się w dniach 10-11 grudnia 1433 r., bowiem już 12 tego miesiąca do Łęczycy przybyli posłowie krzyżaccy w celu wznowienia rozmów. Tym razem strony doszły do porozumienia i przedłużono rozejm na kolejne 12 lat. Układ ten wszedł w życie 31 grudnia, w konsekwencji czego wyprawa została odwołana. Pomimo to nad relacją krakowskiego kanonika warto się zatrzymać, bowiem zawiera ona ciekawe szczegóły dotyczące fazy bezpośrednio poprzedzającej wyruszenie rycerstwa na wojnę. Jeśli mu wierzyć, jednym $z$ argumentów za przeprowadzeniem ataku zimą miała być możliwość przeprawienia wojsk przez Wisłę po lodzie, który pokrywał wówczas rzekę. Szykujące się do wyprawy rycerstwo, jak pisze kronikarz, zabierało ze sobą „to, co było potrzebne dla przezwyciężenia zimna”. Długosz zauważa, że wojnę wyznaczono z wielkim pośpiechem. Brak czasu mieli odczuwać nie tylko rycerze, ale też sam król, obawiający się, że nie uda się zebrać pieniędzy, należnych rycerstwu wyruszającemu na wojnę za granicami Królestwa ${ }^{66}$.

Jak wynika z przytoczonych wyżej informacji o przebiegu mobilizacji, czas potrzebny na zebranie armii zależał m.in. od jej rodzaju. W przypadku expeditio particularis potrzeba było na to od 2 do 4 tygodni. Bardziej czasochłonny był proces formowania armii w przypadku ogłoszenia expeditio generalis. W związku z tym, że przy tego rodzaju wyprawach pod broń powoływano zbrojnych z ziem bardziej odległych od miejsca koncentracji, należało dać im więcej czasu na przygotowanie i dotarcie na miejsce zbiórki. W takich przypadkach król, szykując się do wojny z zakonem, rozsyłał wici na 6-8 tygodni przed rozpoczęciem działań. Więcej czasu dostało wojsko na przygotowania do wojny ze Świdrygiełłą (1431). Król rozesłał wówczas wici z ponad 10-tygodniowym wyprzedzeniem. Mimo to - jak wiadomo - Wielkopolanie dotarli na Ruś z opóźnieniem. Dane te potwierdzają zatem spostrzeżenie Długosza odnoszące się do mobilizacji z przełomu 1433 i 1434 r. - 4 tygodnie na przeprowadzenie pełnej mobilizacji to znacznie mniej niż zazwyczaj wojsko miało w takiej sytuacji.

${ }^{66}$ DŁugosz, ks. 11 i 12 (1431-1444), s. 119; A. GĄsiorowski, op. cit., s. 124; M. Biskup, op. cit., s. 187. 
Jeśli chodzi o czas trwania samych działań zbrojnych, to wyprawy organizowane z części Królestwa trwały zwykle 2-5 tygodni. Można przyjąć, że powrót do domów zajmował przeciętnie około tygodnia. Zatem rycerz powołany na wyprawę częściową, licząc czas dotarcia na miejsce koncentracji, udział w kampanii i powrót do domu, spędzał poza domem zazwyczaj 4-8 tygodni, choć zdarzały się ekspedycje trwające krócej.

Udział w expeditio generalis oznaczał dla jej uczestników wyprawę znacznie dłuższą. Ekspedycje z czasów Jagiełły, licząc od wkroczenia na terytorium wroga, do jego opuszczenia, trwały od 6 do 13 tygodni ${ }^{67}$. Do tego trzeba mieć na uwadze, że powrót z takiej wojny mógł zająć uczestnikom 1-6 tygodni, w zależności, w jakim oddaleniu od miejsca walk zamieszkiwali. Łącznie zatem udział w pospolitym ruszeniu mógł pociągał za sobą konieczność opuszczenia domu na okres od 8 do 18 tygodni.

Na uwagę zasługują też sytuacje, gdy nastąpiła mobilizacja pospolitego ruszenia, przybyło ono na miejsce koncentracji, lecz do wojny nie dochodziło i ostatecznie rycerstwo odsyłano do domów. Tak było w przypadku stycznia 1411 r., a także latem 1419 r., kiedy zwołano pospolite ruszenie do walki z zakonem oraz w 1426 r., gdy Jagiełło wysłał rycerstwo z ziem ruskich jako wsparcie dla Zygmunta Luksemburskiego planującego wojnę z Turcją. Wojsko to dotarło na miejsce koncentracji w okolice Turnu-Severin nad Dunajem na św. Jana Chrzciciela (24 czerwca), jednak ostatecznie do wojny nie doszło i oddziały wróciły na Ruś. Choć udało się uniknąć rozlewu krwi, to ekspedycja z pewnością była uciążliwa dla uczestniczącego w niej rycerstwa. Musiało ono bowiem pokonać dystans ponad $1500 \mathrm{~km}$, co zająć mu musiało co najmniej 14 tygodni ${ }^{68}$. Przez ten czas rycerze byli oderwani od swych rodzin i gospodarstw, musieli znosić trudy kampanii. Na tym jednak nie koniec uciążliwości, jakie niósł ze sobą udział w wyprawie wojennej. Pamiętać należy, że rycerz zobowiązany był do służby na własny koszt. Wprawdzie mocą przywileju piotrkowskiego z 1388 r., król miał obowiązek wypłacić 5 grzywien na jedną kopię, czyli trzech jeźdźców uczestniczących w wyprawie zagranicznej, to jednak postanowienie to nie dotyczyło szlachty ziem ruskich. Zatem wydatki związane z udziałem w tej ekspedycji ponieść musieli sami rycerze ${ }^{69}$. Warto zaznaczyć, że odwołanie wyprawy sprawiało, że jej uczestnicy nie mogli liczyć na

${ }^{67}$ Przy czym tylko w $1414 \mathrm{r}$. kampania trwała 6 tygodni, wyprawa łucka w $1431 \mathrm{r}$. - około 7 tygodni, 1422 r. -8 tygodni, 1410 r. - 11 tygodni, 1433 r. - 10 tygodni Małopolanie, 13 tygodni Wielkopolanie i czeskie „sierotki”.

${ }^{68}$ Zakładam tempo $20 \mathrm{~km}$ dziennie, do tego należy doliczyć dłuższe postoje, jakie armia odbywała podczas dłuższych przemarszów oraz czas oczekiwania nad Dunajem na wojska Zygmunta. Pomijam natomiast dystans, jaki uczestnicy tej wyprawy musieli pokonać ze swych domów na miejsce koncentracji.

${ }^{69}$ Vide: K. Ginter, op. cit., s. 350-351. 
żadne wojenne trofea, może za wyjątkiem tych, które wydarli cywilnej ludności zamieszkującej ziemie, przez które przechodziła armia.

Kolejne zagadnienie, któremu warto się przyjrzeć to kwestia działań wojsk Jagiełły na przestrzeni roku. Analizując kalendarium pod tym kątem, zwraca uwagę fakt, iż armia sporadycznie operowała w pierwszym półroczu, zdecydowanie więcej aktywności wykazując $\mathrm{w}$ drugiej połowie roku. W ciągu pierwszych 6 miesięcy roku expeditio generalis zwołano tylko raz - w styczniu $1411 \mathrm{r}$., co wymuszone było przeciągającą się wojną z zakonem. Jak wyżej wspomniano, zebrane wówczas wojsko nie zdążyło podjąć walki i po zawarciu pokoju toruńskiego (1 lutego) niezwłocznie je rozpuszczono. Pozostałe działania w pierwszej połowie roku to krótkie wyprawy z udziałem rycerstwa jednej prowincji (expeditio particularis) przeciwko Władysławowi Opolczykowi $(1387,1393,1394)$. Na przełom kwietnia i maja przypadła trwająca około miesiąca wyprawa Małopolan z Władysławem Jagiełłą do Wielkopolski w 1386 r., która trwała około jednego miesiąca. Z kolei działania rycerstwa z ziem ruskich wiosną $1433 \mathrm{r}$. miały charakter obronny, wymuszony przez najazd wojsk Świdrygiełły. Listę aktywności militarnej w miesiącach wiosennych zamknąć należy ekspedycją szlachty ruskiej wysłanej na wojnę z Turkami w $1426 \mathrm{r}$.

Generalnie więc pierwsza połowa roku była okresem zdecydowanie mniejszej aktywności wojsk niż jego druga połowa. Działania prowadzono wówczas z użyciem mniejszych sił, zwykle było to rycerstwo jednej prowincji, a same działania wojenne trwały krócej niż te prowadzone w drugiej połowie roku. Bez wątpienia wpływ na to miały warunki klimatyczne. Wprawdzie zima ułatwiała przeprawy przez bagna i rzeki, które o tej porze roku skuwał lód, to jednak warunki życia w obozie wojennym stawały się znacznie bardziej uciążliwe - wzrost zachorowań czy ograniczony dostęp do żywności obniżały wartość armii, zwłaszcza jeśli miała prowadzić działania na terenie przeciwnika, co wiązało się z wydłużeniem dróg zaopatrzeniowych. Dotyczyło to zarówno ludzi, jak i koni ${ }^{70}$. W konsekwencji, jeśli dochodziło do działań przy niekorzystnych warunkach klimatycznych, używano sił mniej licznych, które operowały przez krótszy czas. Powoływanie w tym okresie rycerstwa $\mathrm{z}$ terenu całego kraju zdarzało się wyjątkowo i nie dochodziło do jego użycia w boju. Z kolei wiosną, choć temperatury były wyższe, to przemieszczanie się wojsk utrudniały roztopy. Na przednówku, podobnie jak zimą, trudno też było zaopatrzyć się w żywność.

Z siedmiu wypraw z całego Królestwa Polskiego, jakie ogłosił w okresie swego panowania Władysław II, aż sześć przypadło na drugie półrocze. Wprawdzie przygotowania do ekspedycji ruszały wiosną, a przemarsze wojsk odbywały się u samego schyłku tej pory roku, to regułą było, że działania wojenne zaczynano

${ }^{70}$ O zapotrzebowaniu koni na paszę oraz związanych z tym kosztach vide: J. SzymCZAK, Rycerz i jego konie, Warszawa-Bellerive-sur-Allier 2018, s. 245-250. 
w lipcu. Z kolei działania zbrojne kończono we wrześniu, tylko w 1409 i 1414 r. nastąpiło to na początku października. W tym pierwszym przypadku wynikało to $\mathrm{z}$ rozpoczęcia działań we wrześniu, będących odpowiedzią na sierpniowy krzyżacki atak. Król był wówczas zmotywowany do odbicia Bydgoszczy z rąk krzyżackich i przerwał działania dopiero, kiedy to się udało. Na przełomie września i października 1393 r. prowadzono kampanię przeciwko Opolczykowi, w której uczestniczyło rycerstwo krakowskie. Podobnie rzecz się miała w 1391 r., wtedy część wojsk pozostawała pod bronią nawet do listopada, ale były to działania o zdecydowanie lokalnym charakterze, sprowadzały się do oblężenia Bobrownik. Spośród 18 konfliktów, które trwały w drugiej połowie roku, zaledwie 3 wymusiły służbę rycerstwa w listopadzie i grudniu ${ }^{71}$. Dwukrotnie wynikało to z chęci - lub konieczności - doprowadzenia do pomyślnego zakończenia wcześniej rozpoczętych wojen. Tak się stało w przypadku wspomnianych wyżej walk o Bobrowniki, czy konieczności utrzymania wojska w 1410 r., by wymusić na zakonie zawarcie pokoju. Trzeci przypadek prowadzenia walk u schyłku roku wymuszony został koniecznością obrony Podola w związku z najazdem wojsk Świdrygiełły w 1432 r.

Średniowieczne armie były wprawdzie w stanie operować w ciągu całego roku, lecz działania zimą czy wiosną utrudniały niskie temperatury oraz problemy z zaopatrzeniem. Działania zimową porą były możliwe do prowadzenia, lecz traktowano je jednak jako ostateczność. Dążono do tego, aby uniknąć kontynuowania kampanii o tej porze roku, odwołując wojska przy nadarzającej się sposobności. Jeśli już doszło do działań zbrojnych, zwykle angażowano mniejsze siły, kampanie trwały krócej niż te, które toczyły się w ciepłej porze roku. Operacje zaczepne $\mathrm{z}$ udziałem wielkich armii złożonych z rycerstwa z obszaru całego Królestwa lub przynajmniej dwóch głównych prowincji prowadzono latem, sporadycznie przeciągając działania do pierwszych dni jesieni. Można zatem w pewnym uproszczeniu stwierdzić, że pospolite ruszenie w czasach Jagiełły funkcjonowało w zgodzie z naturą, stawało się aktywne, gdy robiło się ciepło, a przyroda była w pełnej krasie. Wraz nadejściem chłodów i opadnięciem liści armia zapadała w sen zimowy, z którego z rzadka tylko i niechętnie była wybudzana.

Okres panowania Władysława Jagiełły to czas wielu sukcesów armii rycerskiej Królestwa Polskiego. Choć polityczne rezultaty toczonych wówczas wojen mogły niekiedy rozczarowywać, to pod względem militarnym ich przebieg należy generalnie ocenić pozytywnie. Regularnie prowadzone działania sprawiały, że armia nabierała doświadczenia zarówno w kwestiach organizacyjnych, jak i bojowych. W przypadku wojen z zakonem krzyżackim widoczny jest schemat przygotowań polegający na korzystaniu z tych samych miejsc koncentracji (lub położonych

${ }^{71}$ Było to oblężenie Bobrownik w listopadzie 1391 r., mająca defensywny charakter mobilizacja rycerstwa wielkopolskiego w 1410 r. obejmująca okres od października do grudnia oraz działania rycerstwa ziem ruskich w 1432 r. mające na celu obronę Podola najechanego przez wojska Świdrygiełły. 
w pobliżu), szlaków, regularnym korzystaniu z przeprawy przez Wisłę po pływającym moście. Również pora prowadzenia tych kampanii wojennych była praktycznie ta sama i przypadała na lato. Zapewne także indywidualnie, uczestnicy kolejnych kampanii podnosili swe umiejętności i stawali się lepszymi rycerzami. W latach 1409-1422 król powoływał rycerstwo pod broń siedmiokrotnie, a więc co dwa lata. Ta częstotliwość i regularność wypraw do Prus przyczyniała się do podnoszenia walorów armii królewskiej. $Z$ drugiej jednak strony dają się w tym czasie zauważyć pierwsze problemy z funkcjonowaniem tych wojsk. Rycerz uczestniczący w wyprawie przeciwko zakonowi - w zależności od miejsca zamieszkania - zmuszony był często opuścić dom na około 4 miesiące, przypadające na czas żniw. Dla tych, którzy mieszkali dalej od terenu objętego wojną, okres ten był jeszcze dłuższy.

Taki sposób prowadzenia wojen był dla szlachty nie tylko uciążliwy, ale i kosztowny. Kwota 5 grzywien na kopię, którą od 1388 r. król miał wypłacić uczestnikom wyprawy poza granice Królestwa, nie pokrywała w pełni kosztów ich udziału w kampanii. Na dodatek Jagiełło uchylał się niekiedy od wypłacania rycerstwu należnych sum ${ }^{72}$. W końcowym okresie rządów Jagiełły, jego relacje z rycerstwem zaczynają ulegać pogorszeniu. W 1419 r. odwołanie wyprawy przeciwko zakonowi wywołuje w szeregach armii niezadowolenie, ekspedycja z $1422 \mathrm{r}$. jest okazją do wymuszenia na Jagielle przywilejów, a w 1431 r. pospolitacy z Wielkopolski spóźniają się na miejsce koncentracji wojsk, po drodze łupiąc własny kraj. Z lat 30. XV w. pochodzą informacje o dezercji i unikaniu służby przez szlachtę $e^{73}$. Jak widać, lata panowania Władysława II to nie tylko okres wojennych sukcesów, ale też czas, w którym pospolite ruszenie zaczynało przysparzać władcy problemów. Kolejne wojny, zwycięskie bitwy oraz długie miesiące spędzane przez rycerstwo w obozach wojennych dały mu poczucie siły nie tylko wobec wroga, ale i własnego króla. Następcy Jagiełły mieli to odczuć jeszcze mocniej. O ile kalendarz działań pospolitego ruszenia był w zgodzie z rytmem natury, o tyle trudno nie zauważyć, że dla sporej części rycerstwa w tym czasie naturalnym miejscem egzystencji stało się gospodarstwo, a nie pole bitwy.

72 Vide: wyżej.

73 A. Gąsiorowski, Pobór..., s. 132-135; A. Prochaska, Przywilej czerwiński z 1422 r., „Przegląd Historyczny” 1907, t. IV, s. 282-296; K. Tymieniecki, Przyczynki archiwalne do dziejów w. XV, „Roczniki Historyczne” 1933, nr 1, s. 226-233; nr 2, s. 100-115. 


\title{
Tadeusz Grabarczyk
}

\section{THE WAR CALENDAR OF THE GENERAL LEVY OF NOBILITY IN THE TIMES OF WŁADYSŁAW JAGIEŁŁO}

\begin{abstract}
Summary: This article concerns the participation of knights in wars during the reign of Władysław Jagiełło (1386-1434). Its goal is to determine how often and for how long the king called up the army, which will allow to assess how absorbing war expeditions were for knights at that time. The analysis shows that the king called knights 22 times minimum, of which the army from all over the Kingdom of Poland (expeditio generalis) was issued seven times, the remaining mobilizations concerned knights from one province (expeditio particularis). In addition, there were also smaller-scale defensive clashes, mainly near the Polish borders with the Teutonic Order and Silesia (defensio terrae). From the announcement of mobilization to the gathering of troops, it took from 2 to 8 weeks, this time depended on whether the expedition from one province or the whole Kingdom was convened. Preparations for the latter took longer, because the knights needed more time to get to the place of concentration of troops. In the case of local activities, the fighting was carried out for 2-4 weeks, in the case of expeditio generalis the campaigns lasted 8-13 weeks. During the most intense war period of 1409-1422, knights were called up to eight times. Participation in wars was absorbing for knights. Most of the conflicts took place in the summer, which forced the nobility to leave their farms at harvest time. Participation in the wars was costly, and the king refused to pay any remuneration for participating in the expedition abroad, despite his commitment to do so in 1388. Starting from 1419, the deterioration of the relationship between the king and the knights during expeditions can be seen. Worsening of discipline in the army becomes apparent.
\end{abstract}

Keywords: Władysław Jagiełło, Poland, wars, $15^{\text {th }}$ century, knights, general levy. 